\title{
Technical Entrepreneurship in Small Repairing Firms: A Study on Motorbike Repairing Workshops in Sylhet City
}

\author{
ABDUL LATIF* \\ KHANDAKER DAHIRUL ISLAM ${ }^{* *}$ \\ TOUHEDA YASMIN CHOWDHURY ${ }^{* * *}$
}

\begin{abstract}
This research straightforwardly dilates the real scenario with an attempt to deal with all issues regarding motorbike workshops in Sylhet City, Bangladesh. Though analyzing the managerial activities appears as one of the core concerns of the research, it identifies the opportunities of entrepreneurial development for innovative and technically skilled persons. Through the observation of the formation and operational activities of such kind of workshops, the research attempts identifying problems faced by those firms, and eventually tries to produce solutions in that problem domain in the form of suggestions. The work has an endeavor to find out the historic pattern of the establishment of this kind of enterprise that helps understand whether the entrepreneurs are chronically affected by their families. The empirical study of the research also approaches to examine whether assistance from the government and NGOs to setup and to operate this type of entrepreneurship is required.
\end{abstract}

Key Words: Motorbike Workshop, Management Activities, Entrepreneurship, Problems and Solutions, Unemployment Problem.

\section{INTRODUCTION}

The word entrepreneur has its origin in the French word "Entrepreneur". It is referred to the organizer of orchestra. An entrepreneur is one who organizes, manages, and assumes the risk of an enterprise. An entrepreneur must be resultoriented, should have confidence, risk taking ability, leadership and

\footnotetext{
* Associate Professor, Department of Business Administration, Sylhet International University, Bangladesh. E-mail: novalatif@gmail.com

** Assistant Professor, Department of Electronics and Communication Engineering, Sylhet International University, Bangladesh, E-mail: to.mithun@yahoo.com

*** Lecturer, Department of Business Administration, Sylhet International University, Bangladesh.E-mail: rima_8597@yahoo.com
} 
communication skill. Entrepreneurs are identified with all sorts of economic activities and exist also in all social and cultural systems.

The classification of entrepreneur in business system can be done on the basis of different factors like stage of development, technology factor and type of business. On the basis of technological factors, entrepreneurs are divided into technical and non-technical entrepreneurs. Technical entrepreneur is one with a technical skill base, has access and expertise in chosen technical area and produces goods and /or services by making use of best available technology. On the other hand, non- technical entrepreneurs concerned with marketing and distribution aspects of products and services and develop strategy in those areas to promote business. They are concerned with their specification, utilities and functions of the product.

A repair is something that one does to mend a machine, building, piece of clothing or other things that has been damaged or is not working properly. There are many repairing workshops in a city to provide repair service to consumers whose products are not working properly because of difficulties. A motorbike or motorcycle is a vehicle with two wheels and an engine.

\section{Why do people choose motorcycle?}

It is the most affordable and popular among vehicles. There are 200 million motorcycles in use worldwide. The user rate is 33 per 1000 people. Most of motorcycle users are in India, China and other Asian countries. As an Asian country, Bangladesh is also the home of one of the largest motorcyclist countries. The users are increasing. Sylhet is a divisional city of Bangladesh with a population of 463,198 in 2008. As a foreign remittance flooded area, people of Sylhet are generally well-off. So, motorcycle users (per 1000 people) are the highest in Sylhet among Bangladesh according to the interview with the personnel of Motorcycle Seller Association. From the Bangladesh Road Transport Authority (BRTA) record, the researchers found that the rate of registration in Sylhet is on an average 2500 a year. It is assumed that around 1500 motorcycle are added to the roads of City Corporation area in a year. Naturally, requirements of repairing are also increasing, that results in the increasing demand for repair workshops. 


\section{OBJECTIVES OF THE STUDY}

The objectives of the study are as follows:

i. To present some salient aspects of motorbike workshops of Sylhet city.

ii. To comprehend the entrepreneur- creation pathways of the industry; try to study the formation of motorbike repairing enterprise.

iii. To study the marketing-related dimensions of the industry.

iv. To find out different challenges facing the industry and suggest some solutions, giving special importance to entrepreneur-creation process.

\section{METHODOLOGY, DATA FOR THE STUDY, LIMITATIONS}

The study is an empirical one, based mainly on primary survey data. We collected primary data by structured questionnaire interviewing the motorbike workshop owners. We also observed the operation of the workshops by visiting the sample workshops. We complemented our primary data with secondary data/information from relevant websites, newspapers and journals. The sample survey was carried out in June to August, 2012. Trained university students helped the researchers to collect the data. The sample size is below 30; hence there are some statistical limitations. The survey-results are not generalizable. They are indicative.

\section{FINDINGS AND ANALYSIS}

\subsection{Socio-economic Characteristics of the Motorbike Repair Entrepreneurs:}

In the analysis of socio-economic characteristics of the motorbike repair entrepreneurs, the researchers covered the age, qualification and working experiences in order to depict the entrepreneurs' generation process by motorbike repair workshops of Sylhet city. To know the family background of the entrepreneurs their fathers' occupations are also studied.

\subsubsection{Owners' profile}

Usually people of above 50 years age are unwilling to set up a new enterprise due to risk. At the age of 25-35 years, people are ready to take risks of establishing new enterprise [Nazrul, 2000]. 
TABLE 2

PROFILE OF ENTREPRENEURS

\begin{tabular}{|l|l||l|l|l||l|l|}
\hline \multicolumn{2}{|c||}{ Age Distribution } & \multicolumn{2}{c||}{ Educational Qualification } & \multicolumn{2}{l|}{ Working Experience } \\
\hline Years & Frequency & Level & Frequency & $\begin{array}{l}\% \\
\text { share }\end{array}$ & Years & Frequency \\
\hline Below 20 & 0 & Primary level & 03 & 11.54 & $0-2$ & 00 \\
\hline $20-24$ & 3 & Class 5- 8 & 17 & 65.38 & $2-4$ & 02 \\
\hline $25-29$ & 7 & Class 8-10 & 04 & 15.38 & $4-6$ & 12 \\
\hline $30-34$ & 10 & $\begin{array}{l}\text { SSC } \\
\text { (Secondary } \\
\text { Certificate) }\end{array}$ & 01 & 3.85 & $6-8$ & 08 \\
\hline $35-39$ & 5 & SSC-above & 01 & 3.85 & 8 -above & 04 \\
\hline $40-$ above & 2 & & & & & \\
\hline Total & 26 & Total & 26 & $\mathbf{1 0 0 . 0 0}$ & Total & 26 \\
\hline Mean & 31.26 & $\begin{array}{l}\text { Median } \\
\text { Class }\end{array}$ & $\begin{array}{l}\text { Below } \\
\text { Class 8 }\end{array}$ & & Mean & 7.6154 \\
\hline $\begin{array}{l}\text { Std. } \\
\text { Deviation }\end{array}$ & $\mathbf{5 . 5 0}$ & Modal Class & $\begin{array}{l}\text { Below } \\
\text { Class 8 }\end{array}$ & $\begin{array}{l}\text { Std. } \\
\text { Deviation }\end{array}$ & $\mathbf{2 . 5 8}$ \\
\hline
\end{tabular}

Source: Own field survey from June 2012 to August 2012

In this research, it is also found that the modal age of entrepreneurs starting new workshop is 30-34. The arithmetic mean of age of entrepreneur is 31.26 and SD 5.50 .

\subsubsection{Educational Qualifications}

Studies show that more entrepreneurs are created among the technical specialist [Nazrul, 2000]. In that type of entrepreneurship, to know the technical know-how of motorcycle, many are working from their childhood in the different workshops to become a workshop owner in future. So, formal education becomes impossible for them. The above Table 2 reveals the truth regarding the educational qualification of the entrepreneurs. This Table reveals the fact that more than $92 \%$ entrepreneurs' educational qualification is below 10 grade. Around $65 \%$ of them are educated between grade 5-8.

\subsubsection{Working experience of the entrepreneurs in other workshop}

Entrepreneurs give birth to entrepreneurs. Working in a workshop under an entrepreneur for some years is highly useful to gather technical know-how and establish network with the motorbike owner to start a new venture; it is the starting point of new entrepreneurs. A study shows that on an average the workshop entrepreneurs have an working experience of 6 years with a standard 
deviation of 2.8 years [Nazrul, 2006]. It is found that, the arithmetic mean of working experience of the entrepreneurs in other workshop is 6.08 and SD 1.89.

\subsubsection{Entrepreneurs' father's occupational backgrounds}

The following Figure 1 shows the history of the occupation of the fathers of entrepreneurs regarded in this research. It will help understand whether the people come to this business following a family tradition or not.

FIGURE 1: Distribution (percent) of Entrepreneurs' Fathers Occupations

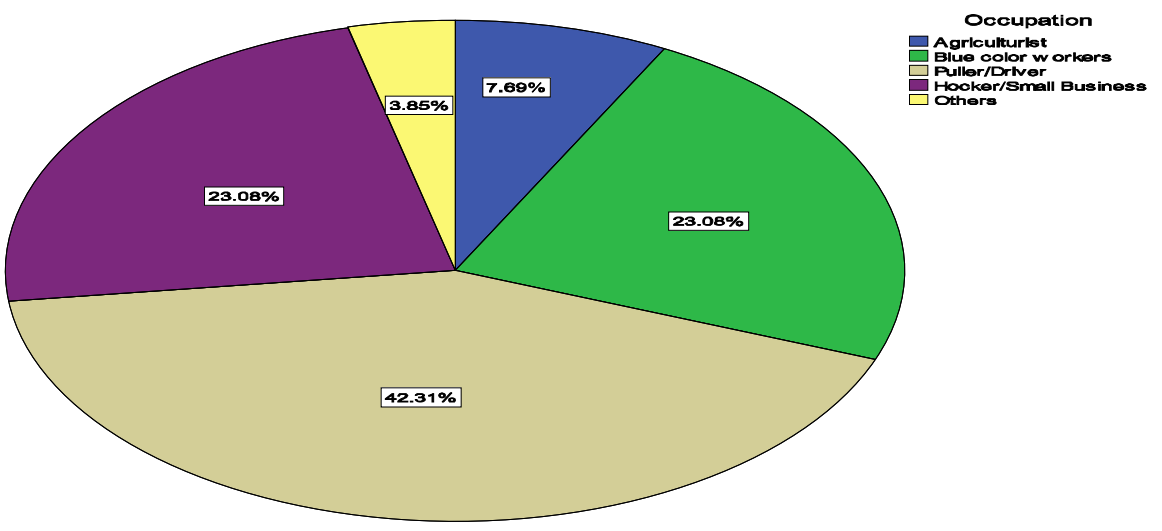

Source: Own field survey from June 2012 to August 2012

The above figure identifies that most of the fathers were in the third group (i.e. rickshaw puller, auto rickshaw driver etc.). Another $23.08 \%$ fathers were blue color workers and hawker/ small business people respectively. The figure will also help in guessing the financial base of their families. The rent and advances for the shop is also very high. It was also revealed from the study that the total investment (in current Taka) for such workshop is (Tk. 75,000-Tk. $500,000)$ and $60 \%$ of the entrepreneurs had come from districts other than Sylhet. Around $80 \%$ investment was made by owner's fund, where other contributors in the capital are friends and relatives and bank. Roughly 60\% replied they had to sell their land to collect money for starting such an enterprise.

\subsection{Locations of the workshops:}

The entrepreneurs are distributed according to various areas in the city (see the map in Appendix) as the following Table 3 indicates: 
TABLE. 3

AREA-WISE DISTRIBUTION OF RESPONDENTS

\begin{tabular}{|l|c|c|}
\hline \multicolumn{1}{|c|}{ Locations } & $\begin{array}{c}\text { No. of } \\
\text { workshops }\end{array}$ & \% of workshops \\
\hline Bandar-Zindabazar & 24 & 15.79 \\
\hline Amborkhana-Airport & 18 & 11.84 \\
\hline Subidbazar- Pathantula & 16 & 10.53 \\
\hline Chowhatta-Bagbari & 18 & 11.84 \\
\hline Mirabazar-Shibgonj & 14 & 9.21 \\
\hline Tilaghor- Shahparan & 16 & 10.53 \\
\hline Eidghah- Baluchar & 13 & 8.55 \\
\hline Taltala-Kajirbazar & 15 & 9.87 \\
\hline South Surma & 18 & 11.84 \\
\hline Total & $\mathbf{1 5 2}$ & 100.00 \\
\hline
\end{tabular}

Source: Own field survey from June 2012 to August 2012

The workshops are situated mainly in the area where rents are low. There is no workshop in the super market, shopping mall, i.e. sophisticated area, but in comparatively unpolished area for low rent. Highest number of workshops are in Bandar-Zindabazar area (24) and lowest in the Eidghah - Baluchar area.

Establishing a workshop depends mainly on the availability of shop on rent for that purpose. In the metropolitan area, the cost of land is naturally very high and it is not possible for a person with technical know-how of motorbike and financially not sufficiently sound to buy a land or shop for workshop. In this research, it is known that all the workshops are on the rented shop. But the entrepreneur consider another most important factor about location that, they want to fulfill the vacancy of motorcycle workshop in different areas. But availability of shop plays the significant role as it is shown that, in many places two or more motorcycle workshops were established in same area in a short distance.

\subsection{Workers of the Motorbike Workshop:}

Creation of employment is an indicator of economic development of a country. In Bangladesh, present unemployment rate is 4.5\% [Daily Star, 2012]. So, it is very urgent to create employment opportunities for the unemployed persons. Entrepreneurship play substantial role in solving the problem. Technical 
entrepreneurship contributes substantially as it develops the unskilled persons to be more skilled ones.

TABLE 4

DISTRIBUTION OF EMPLOYMENT AND TRAINING OF WORKERS OF THE WORKSHOPS OF METROPOLITAN AREA

\begin{tabular}{|c|c||l|c|c|}
\hline $\begin{array}{c}\text { Employment } \\
\text { (No. of } \\
\text { person) }\end{array}$ & $\begin{array}{c}\text { No. of } \\
\text { workshops }\end{array}$ & \multicolumn{1}{|c|}{ Training } & $\begin{array}{c}\text { Number of } \\
\text { Entrepreneurs }\end{array}$ & $\begin{array}{c}\text { Percentage } \\
\text { (\%) }\end{array}$ \\
\hline Below 3 & 99 & $\begin{array}{l}\text { Institutional } \\
\text { training }\end{array}$ & 01 & 3.45 \\
\hline $4-7$ & 40 & $\begin{array}{l}\text { On the Job } \\
\text { training }\end{array}$ & 24 & 82.76 \\
\hline $8-10$ & 10 & $\begin{array}{l}\text { Of the job } \\
\text { training }\end{array}$ & 01 & 3.45 \\
\hline Above 10 & 04 & $\begin{array}{l}\text { Training by } \\
\text { manufacturer }\end{array}$ & 03 & 10.34 \\
\hline Total & 153 & Total & $\mathbf{2 6}$ & $\mathbf{1 0 0 . 0 0}$ \\
\hline Mean & 3.91 & Median Class & On the Job & \\
\hline SD & 2.20 & Modal Class & On the Job & \\
\hline & \multicolumn{2}{|l}{ Source: Own field survey from June 2012 to August 2012 } \\
\end{tabular}

The arithmetic mean of employment per workshop is 3.91 and SD 2.20. It means the average employment rate in the sample workshop is not very high.

\section{Technical Skills}

Technical skill to repair the motorcycle is the most important factor for the organizations success. Training for that skill is the only way to make a person skilled. Skill development in motorcycle repairing can be provided in different ways like on the job training (OJT) and off the job. Among the techniques of off the job training, institutional technical training, training organized by manufacturer and workshop itself is worth mentioning. Most of the workshops owners $(66 \%)$ do not have formal technical training from any institutions [Abdullah. 1996]. In this study among motorcycle workshop entrepreneurs, it is found that, $82.76 \%$ managed the sufficient technical skill through training under his supervisor within the workshop. It is a clean case of OJT. 


\subsection{Management of the Financial, Production and Operation, HRM and Marketing}

\section{Financial management}

Finance is a great limiting factor in establishing more workshops by skilled workers. As such entrepreneurs had not come from the family with sufficient financial background, so, the skilled workers had to wait for sufficient fund. It was revealed that at least $25 \%$ workers of the workshop are technically capable to start a new workshop, but due to lack of sufficient capital they are waiting.

No financial management tools are used by the technical entrepreneurs except working capital management. They had to decide about account payable, account receivable, inventory and cash management's decisions. Around $80 \%$ of entrepreneurs enjoy $100 \%$ trade credits. The accounts payable turnover is $5-7$ days i.e. the time to complete the repair and get the payment from motorcycle owners. Roughly $20 \%$ customers enjoy accounts receivable for 5-7 days only. The decisions are made by the owner himself, as there is no paid person's to do the job.

TABLE 5

SOURCE OF NECESSARY FUND OF THE WORKSHOPS

\begin{tabular}{|c|l|c|}
\hline Serial No. & \multicolumn{1}{|c|}{ Source } & Percentage (\%) \\
\hline 1. & Own & 88 \\
\hline 2. & Friends and relatives & 10 \\
\hline 3. & NGO & 00 \\
\hline 4. & Bank & 02 \\
\hline 5. & Others & 00 \\
\hline & Total & $\mathbf{1 0 0}$ \\
\hline
\end{tabular}

Source: Own field survey from June 2012 to August 2012

Investments for establishment of motorbike workshops principally takes place from owners own profile (88\%). However the next way is to make loans from friends and relatives $(10 \%)$. Loan from bank is not very significant and the future owners do have a very meager concern for bank loan (2\%). 


\section{Production and Operation Management}

The key decisions regarding the repair of motorcycle are made by entrepreneur himself. But minor decisions are made by the most skilled worker in the workshops having more than three persons involved. In the biggest four workshops some key decisions are also made by skilled worker. Only $10 \%$ workforce is underutilized in such workshop. About $80 \%$ workshop had to do 1012 hours a day, 6 days a week. Layout of the workshops is done on process basis. Tools are arranged on priority basis. Inventory is maintained on optimum level. Source of necessary instruments/ raw materials are shown here (see Table-6):

TABLE 6

\section{SOURCE OF INSTRUMENTS/PARTS FOR MOTORBIKE WORKSHOP}

\begin{tabular}{|c|l|c|}
\hline $\begin{array}{c}\text { Serial } \\
\text { No. }\end{array}$ & $\begin{array}{c}\text { Source } \\
\text { Origin }\end{array}$ & $\begin{array}{c}\text { Percentage } \\
\text { Share (\%) }\end{array}$ \\
\hline 1. & Own city & 92 \\
\hline 2. & Capital city & 08 \\
\hline 3. & Foreign & 00 \\
\hline 4. & Others & 00 \\
\hline
\end{tabular}

Source: Own field Survey from June 2012 to August 2012

\section{HRM}

The techniques of improving the skill level of the workers, the compensation and fringe benefits, the four P's of Marketing and promotional activities were studied to assess the strength of Human Resource Management and marketing management of the workshops. Manpower planning is done by the entrepreneur himself. On the basis of requirement, the owner recruits unskilled boys in exchange of an allowance of Tk. 15-20 a day without any monthly pay or wages. As per his planning this boy become skilled day by day. The other recruiting methods are shown below (see Figure 2): 
FIGURE 2: Modes of developing skill level of Workers

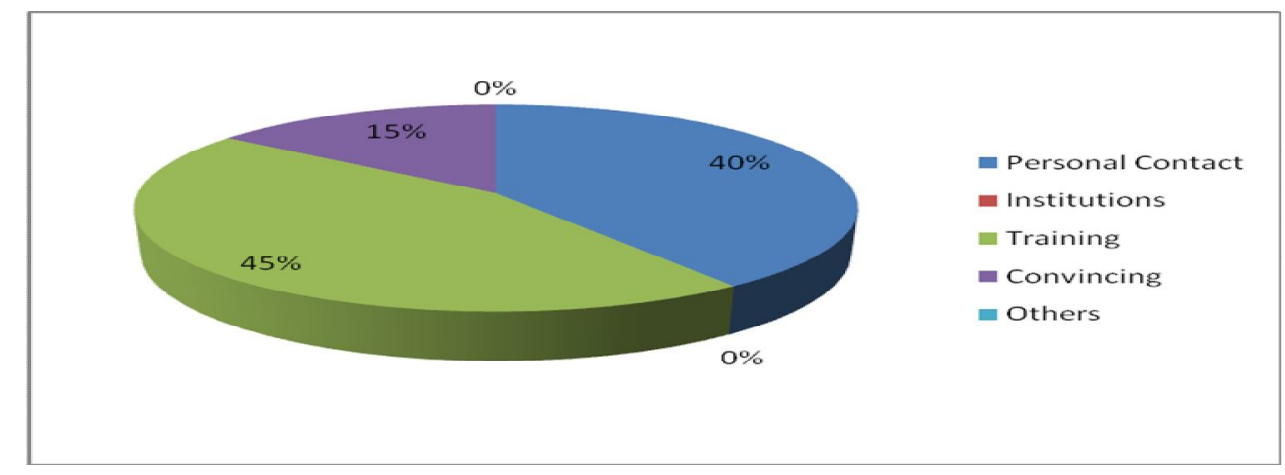

The ratio of skilled and unskilled workers in a workshop on an average is 1:1. The improving through training method is dominating over other methods $(45 \%)$. Besides there is personal contact $(40 \%)$ and most conflicting method among entrepreneurs is convincing from other workshop.

\section{Compensation}

Compensation policy of the workshops owners is very well in monetary term. But the main compensation is done by improving the employee to be an entrepreneur in generally 5-10 years. The compensation package consists of daily allowance, lunch allowance and monthly salary. The range of compensation is given below (Table-7):

\section{TABLE 7
COMPENSATION OF WORKERS}

\begin{tabular}{|c|l|c|}
\hline $\begin{array}{c}\text { Serial } \\
\text { No. }\end{array}$ & Compensation & $\begin{array}{c}\text { Range } \\
\text { (in Tk.) }\end{array}$ \\
\hline 1. & Monthly salary & $1000-5000$ \\
\hline 2. & Allowance & $10-30$ \\
\hline 3. & Pay for lunch & $0-30$ \\
\hline
\end{tabular}

Source: Own field survey from June 2012 to August 2012

No fringe benefits are allowed in such workshop. People after 50 withdraw him from such work. There are no provisions of pensions or grants for workshop employees.

\section{Marketing Management}

The elements of marketing mix are product, place, price and promotion [Pride, 1987]. The product i.e. the repairing quality is strictly maintained to 
provide full satisfactions to the motorcyclists. This is ensured by the entrepreneurs himself in $80 \%$ cases. Rest $20 \%$ is ensured by the most skilled technician of the workshop.

The workshop provides the place facility to its clients. If the motorcycle faces by any accident, the workshop men are sent there to pick it to the workshop or give the necessary service on the spot if possible.

The price element is determined in view of satisfying the client. The service charge is always negotiable. The range of service charge for various services is Tk. 30- Tk. 3000 (in current 2012 Taka). No fixed prices for service are recorded in any workshop.

All promotional elements like salesmanship, advertisement, publicity and sales promotion are not used here. Publicity is the element that dominates (95\%). Various types of publicity (see Table-8) are used like publicity of existing customers, employee-networks, showroom/ garage-based publicity. Signboards are used in almost all enterprises. But the small ones use very unattractive types i.e. only identifying signboards. Around $60 \%$ workshops use attractive signboards for advertisement.

\section{Promotional activities}

Marketing promotion is an important approach of establishing effective communication with target customers. For motorbike workshops, the target customers are the owners of motorbikes who need to repair their vehicles. The tools of marketing promotion are advertisement, personal selling, public relations and sales promotion.

TABLE 8

\section{METHODS OF PROMOTION}

\begin{tabular}{|l|l|l|}
\hline $\begin{array}{c}\text { Elements of } \\
\text { Promotion mix }\end{array}$ & \multicolumn{1}{|c|}{ Methods } & \multicolumn{1}{|c|}{$\begin{array}{c}\text { Used by } \\
(\mathbf{\%})\end{array}$} \\
\hline Public Relation & Existing customers as advertisers & 65 \\
\hline Personal selling & Employees' network & 22 \\
\hline Advertising & Showroom/ garages-based & 10 \\
\cline { 2 - 3 } & Signboards & 3 \\
\hline & Others & 0 \\
\hline & Total & 100 \\
\hline
\end{tabular}

Source: Own field survey from June 2012 to August 2012 
From the Table- 8 above, it is clear that, promotions of workshops are mainly carried on the publicity of existing customers. The sales promotion method is not used by the workshop owners.

\subsection{Challenges Facing Motorbike Workshop}

The challenges faced by the motorbike workshop-owners are multidimensional e.g. in the areas of production and operational, finance, marketing, HRM and environment. The 26 entrepreneurs were requested to mention their key problems from a list provided to them. It is notable that the list is embodied in some possible problems seen by the researchers. From their answer, the Table below (Table.9) has been formulated.

The major operational challenges are high cost of tools and lack of raw materials. Load shedding and unavailability of parts are the others to be mentioned. Finance related problems are not so significant to be mentioned. Price-related problems in marketing are also worth mentioning. As the technicians are getting skilled day by day, they are always in a bargaining position with the owners with financial and other facilities and they have the mindset to start their own workshops, the workshop owners are always under pressure.

Again getting a skilled worker is the top-most priority of workshops. Around $77 \%$ entrepreneurs reported that problem. High cost of raw materials and tools is the next to it, where $58 \%$ of the entrepreneurs responded and third problems as identified is load shedding, lack of training facilities, unavailability of parts negligence by government policies $38 \%$ of the respondents. 
TABLE 9

CHALLENGES ENCOUNTERED BY WORKSHOPS

\begin{tabular}{|c|c|c|c|}
\hline $\begin{array}{l}\text { In } \\
\text { Specific } \\
\text { area }\end{array}$ & Challenges & $\begin{array}{l}\text { No. of } \\
\text { entrepr- } \\
\text { eneurs }\end{array}$ & $\begin{array}{l}\text { Percentage } \\
\quad(\%)\end{array}$ \\
\hline \multirow{7}{*}{$\begin{array}{l}\text { Production } \\
\text { and } \\
\text { Operation }\end{array}$} & 1. High cost of tools & 13 & 50.00 \\
\hline & 2. High cost of raw materials & 15 & 57.69 \\
\hline & 3. Load Shedding & 10 & 38.46 \\
\hline & 4. Unavailability of parts & 10 & 38.46 \\
\hline & 5. Lack of IT knowledge & 08 & 30.77 \\
\hline & $\begin{array}{l}\text { 6. Lack of knowledge about } \\
\text { importing machinery and raw } \\
\text { materials }\end{array}$ & 02 & 7.69 \\
\hline & $\begin{array}{l}\text { 7. Absence of knowledge in } \\
\text { technology for repairing } \\
\text { motorbike }\end{array}$ & 05 & 19.23 \\
\hline \multirow[t]{2}{*}{ Finance } & 8. Risk of investment & 02 & 7.69 \\
\hline & 9. High Interest rate of bank loan & 02 & 7.69 \\
\hline \multirow[t]{2}{*}{ Marketing } & $\begin{array}{l}\text { 10. Unwillingness to fair pay for } \\
\text { service }\end{array}$ & 10 & 38.46 \\
\hline & $\begin{array}{l}\text { 11. Competition from companies } \\
\text { service center }\end{array}$ & 05 & 19.23 \\
\hline \multirow[t]{2}{*}{ HRM } & 12. Lack of training facilities & 10 & 38.46 \\
\hline & 13. Lack of skilled workers & 20 & 76.92 \\
\hline \multirow[t]{5}{*}{$\begin{array}{l}\text { Environm } \\
\text { ental }\end{array}$} & $\begin{array}{l}\text { 14. Threats from local pressure group, } \\
\text { extortions etc }\end{array}$ & 04 & 15.38 \\
\hline & 15. Bureaucratic problems & 00 & 0.00 \\
\hline & 16. Absence of government incentives & 07 & 26.92 \\
\hline & 17. Negligence by govt. policies & 10 & 38.46 \\
\hline & 18. Local pressure for sound pollution & 02 & 7.69 \\
\hline
\end{tabular}

Source: Own field Survey from June 2012 to August 2012

\section{SUGGESTIONS TO OVERCOME THE CHALLENGES}

The most important challenges of these workshops are lack of skilled workers. These are due to the fact that there is no institutional training facility and off the job training is also rare. So, the only way to develop manpower is to on the job training (OJT) by the workshop itself. This method is less costly but very slow as the compensation for training period is meager. The creative persons do not enroll in such industry. Mostly illiterate persons join in such 
workshop; the owners cannot develop them rapidly. So facilities of training are needed to solve the problem. Manufacturers may set up such institutions to supply the technical entrepreneurs to equip the workshop because of increasing trends of motorcycle usages in metropolitan area to avoid traffic jam. Government contribution in this field is much needed as these workshops may flourish due to their innovativeness. To minimize the load shedding, Government's initiatives are needed. Service charge rate may be prepared by the workshop owners and be hanged on the wall of workshop to avoid bargaining.

\section{CONCLUSION}

Entrepreneurs' creation by the simple motorbike workshops is contributing significantly in our economy. The employment opportunity in the industry is also significant. The contribution of such workshop to the increasing business of motorbike sellers must be considered by them. The manufacturers can arrange training program for such innovative persons as the service center of them could not satisfy the consumers because of convenient location. The workshops are scattered around the city and consumers are taking services of them conveniently. The educational and training base of such entrepreneurs could be improved. The financial supports from Governments and NGOs can be used to flourish such innovative workshops. The barriers specially load shedding and toll collecting activities of miscreants must be stopped. 


\section{REFERENCES}

Kent, C.A.; Sexton, D.L. and Vesper, K.H. (1982), Encyclopedia of Entrepreneurship, Englewood Cliffs, edited, New jersey; prentice Hall.

Collins Cobuild Advanced Learner's English Dictionary (2006). Fifth edition. Harpercollins Publishers, Great Britain.

Wikipedia.org/wilki/motorcycle

Wikipedia.org/wilki/Sylhet

Nazrul, Zaman, (2000) Entrepreneurship Development- An operational Approach, The university Press Limited,

Nazrul, Mamun, Abed, (2006) Management of innovative activities of small entrepreneurial manufacturing workshops in Bangladesh, Journal of business Administration, Vol. 32, No 1 \&2, January and April.

The Daily Star, 18 January, 2012.

Pride, Ferrel (1987). Marketing, $5^{\text {th }}$ edition, Houghton Mifflin Company, Boston.

Abdullah. M. (1996), Entrepreneurship development in workshop Manufacturing Industries in Bangladesh: problems and policies, Management Development, Vol. 25, No. 3 July-September. 


\section{APPENDIX}

Study Area of Motorbike Workshops: Bangladesh and Sylhet City

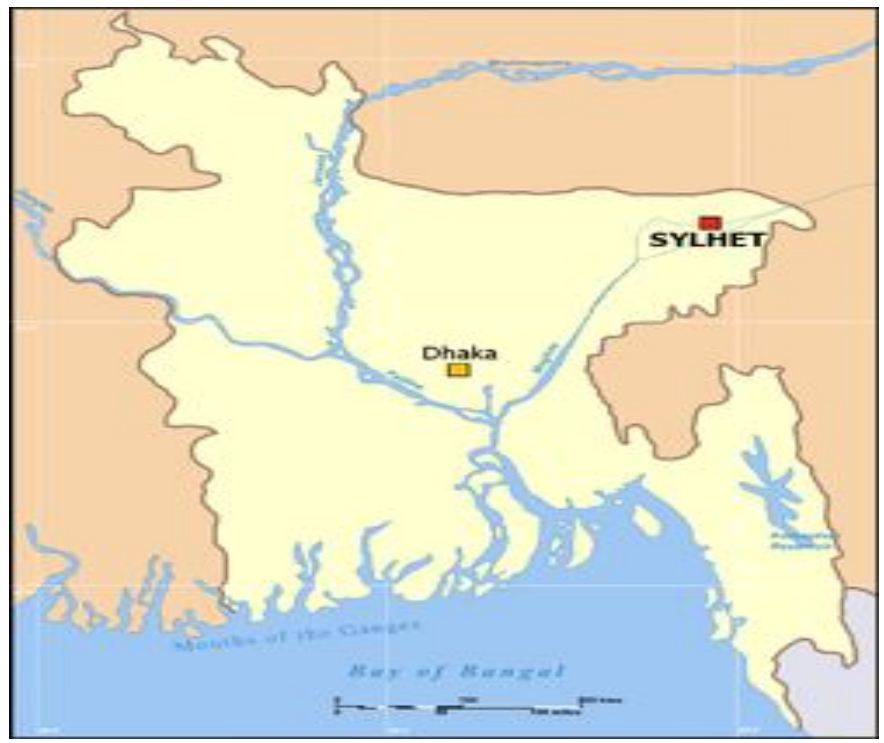

Map: The Sylhet of Bangladesh.

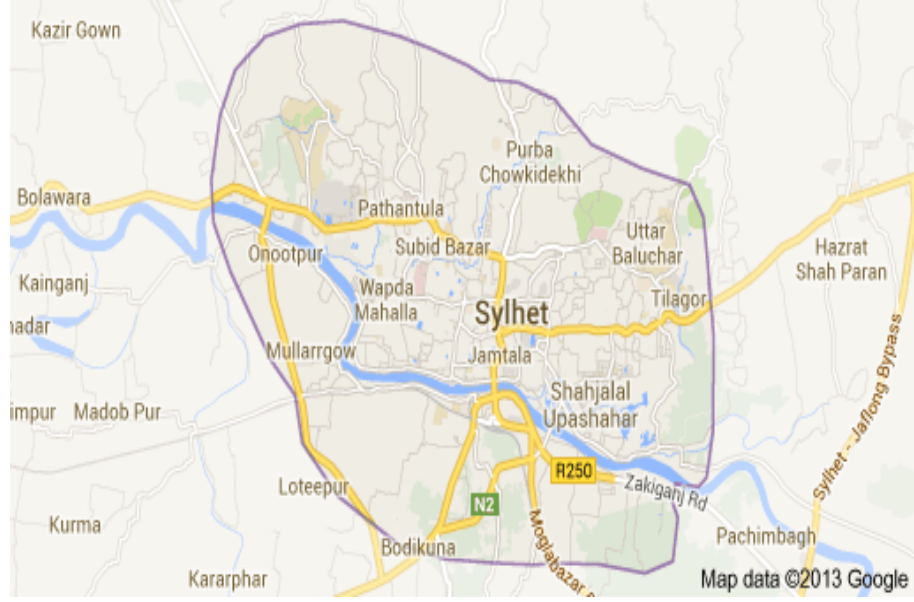

